\title{
Asymptomatic bacteriuria among pregnant women attending antenatal clinic at a tertiary care centre
}

\author{
Barun K. Basumatary, Bijoy K. Dutta, Nabina Choudhury*
}

Department of Obstetrics and Gynecology, Gauhati Medical College, Gauhati, Assam, India

Received: 25 November 2019

Revised: 27 December 2019

Accepted: 03 January 2020

\author{
*Correspondence: \\ Dr. Nabina Choudhury, \\ E-mail: peppypooja90@gmail.com
}

Copyright: (c) the author(s), publisher and licensee Medip Academy. This is an open-access article distributed under the terms of the Creative Commons Attribution Non-Commercial License, which permits unrestricted non-commercial use, distribution, and reproduction in any medium, provided the original work is properly cited.

\begin{abstract}
Background: The term asymptomatic bacteriuria is defined as the presence of $>100,000$ colonies of a single bacterial species per millilitre of urine $(105 \mathrm{cfu} / \mathrm{mL})$, cultured from clean catch midstream sample in the absence of declared symptoms. The aim of this study was to know the incidence of asymptomatic bacteriuria in pregnancy and the various factors influencing it, to identify the pathogens and their antibiotic susceptibility patterns.

Methods: Clean catch mid-stream urine samples were collected from 3000 pregnant women (all trimesters) aged between 18-35 years of age attending the antenatal OPD in GMCH, Guwahati for a period of one year (July 2018June2019). Identification of organisms and antibiotic sensitivity tests were performed as per standard methods.

Results: In our study, incidence of asymptomatic bacteriuria was found to be $12.1 \%$. Most women $(52.89 \%)$ were in the age group of (20-30) years, mostly in second trimester $(47.1 \%)$. Gram negative organisms were the commonest organisms isolated; among which Escherichia coli $(56.75 \%)$ was the principal urinary pathogen followed by Klebsiella sp (14.33\%) and Staphylococcus saprophyticus (12.67\%). The isolates were most sensitive to Nitrofurantoin $(87.88 \%)$.

Conclusions: Asymptomatic bacteriuria is common in pregnancy. Once ASB is recognized during pregnancy, it should be appropriately treated with antibiotics and promptly followed up.
\end{abstract}

Keywords: Asymptomatic bacteriuria, Significant bacteriuria, Urinary tract infection

\section{INTRODUCTION}

Urinary tract infection (UTI) is one of the most common bacterial infection and second most common bacterial infection seen during pregnancy. ${ }^{1,2}$

The term Asymptomatic bacteriuria was introduced by Kass (1960) to emphasize that urinary tract infection cannot be diagnosed by symptoms alone and that certain pregnant women did not manifest any symptoms of UTI yet had bacteriuria. He defined asymptomatic bacteriuria as "a bacterial colony count greater than 105 per millilitre of freshly voided urine in at least two consecutive clean catch mid-stream samples". Asymptomatic bacteriuria (ASB) is an entity with serious consequences in the form of fetal and maternal morbidity and mortality which if not treated, can cause maternal anemia, acute pyelonephritis recurrent infection, preterm labour, septicaemia and even death of the mother. ${ }^{3-5}$ It can also cause intra uterine growth restriction, prematurity and low birth weight of the fetus and even fetal mortality. ${ }^{5-7}$

The incidence of ASB is reported to range between $(2.5 \%-13.2 \%)$, in recent studies that has been conducted in Nigeria, Brazil and India. ${ }^{8-10}$ Follow up cases of ASB which fail to respond to treatment or in which the 
condition recurs show a higher incidence of renal pathology.

Asymptomatic bacteriuria has a definite relation with anaemia, toxaemia and urinary tract infection which are very common in this part of the country, hence it was thought worthwhile to undertake a study on asymptomatic bacteriuria in pregnancy in Gauhati Medical College and Hospital with the following objectives;

- To find out the incidence of asymptomatic bacteriuria in pregnancy.

- To evaluate various factors influencing the incidence.

- To identify and isolate the different kinds of organisms responsible for asymptomatic bacteriuria and to determine their antibiotic susceptibility pattern.

\section{METHODS}

Time bound, analytical, observational, prospective cohort study. Conducted in obstetrics and gynaecology department, Gauhati Medical College and Hospital, Guwahati. Over a period of one year from July 2018 to June 2019. The present observational study was done on 3000 pregnant women in between (15-35) years of age, attending the antenatal OPD of $\mathrm{GMCH}$, obstetrics and gynaecology department and were followed up till delivery.

Subjects who were willing to participate were recruited into the study with informed and valid consent after fulfilling inclusion and exclusion criteria.

\section{Inclusion criteria}

- All pregnant female in between 18-35 years of age with varying gestational period attending ANOPD in $\mathrm{GMCH}$ without the symptoms of urinary tract infection
- For convenience of follow-up, patients from the city itself were selected and followed up till delivery, to note their maternal and perinatal morbidities.

\section{Exclusion criteria}

- All pregnant women with symptoms of urinary tract infection

- Pregnant women on antibiotic therapy or with history of treatment with antibiotics two weeks prior to their antenatal visit

- Pregnant women with pre-existing renal diseases and/or renal calculi, with diabetes mellitus or gestational diabetes

- Women who are not willing for participation in this study.

Urine samples were collected by standard mid-stream "clean catch" method from all the pregnant women, in sterile, wide mouthed containers that were covered with tight-fitting lids. Standard microbiological techniques were used to process the samples. The urine specimens were cultured on plates of MacConkey's agar, Sheep Blood agar. The organisms were identified by routine methods from the samples and the results of culture were interpreted as significant and insignificant according to the standard criteria.

\section{RESULTS}

Table 1 shows that out of the study population of 3000 subjects, 363 patients $(12.1 \%)$ were found to have significant bacteriuria, whereas 2637 (87.9\%) cases had no bacteriuria. Hence, the incidence is calculated to be $12.1 \%$ in our study.

Table 1: Number of patients with significant bacteriuria.

\begin{tabular}{|lll|}
\hline Study population - $\mathbf{3 0 0 0}$ & \\
\hline Significant bacteriuria & 363 & $12.1 \%$ \\
\hline Without bacteriuria & 2637 & $87.9 \%$ \\
\hline Total & $\mathbf{3 0 0 0}$ & $\mathbf{1 0 0 \%}$ \\
\hline
\end{tabular}

Table 2: Age distribution of patient.

\begin{tabular}{|lrllll|}
\hline Age in years & No. of cases & Percentage & Significant bacteriuria & Percentage & Significance \\
\hline$<20$ & 463 & 15.43 & 64 & 17.63 & \\
\cline { 1 - 5 } $20-30$ & 1653 & 55.1 & 192 & 52.89 & $\mathrm{p}<0.0001$ \\
\hline$>30$ & 884 & 29.47 & 107 & 29.48 \\
\hline Total & $\mathbf{3 0 0 0}$ & $\mathbf{1 0 0}$ & $\mathbf{3 6 3}$ & $\mathbf{1 0 0}$ \\
\hline
\end{tabular}

Table 2 maximum number of patients belong in the age group between (20-30) years i.e. 192 patients, highest percentage of significant bacteriura i.e. $52.89 \%$ is seen in this age group. Lowest percentage of $17.63 \%$ cases were seen in patients of age of $<20$ years. Table 3 highest percentage of cases i.e. $47.1 \%$ is seen in second trimester followed by $29.48 \%$ cases in third trimester. Least cases i.e. $23.42 \%$ have been identified in first trimester. 
Table 4 shows the different type of organisms isolated in asymptomatic bacteriurics during pregnancy, Escherichia coli being the commonest organism isolated in 206 $(56.75 \%)$ patients.

Table 3: Relation of ASB according to period of gestation.

\begin{tabular}{|c|c|c|c|c|c|}
\hline Trimester & No. of cases & Percentage & $\begin{array}{l}\text { No. of positive cases with } \\
\text { significant bacteriuria }\end{array}$ & Percentage & Significance \\
\hline $1^{\text {st }}$ Trimester & 975 & 32.5 & 85 & 23.42 & \multirow{3}{*}{$\mathrm{p}<0.0001$} \\
\hline $2^{\text {nd }}$ Trimester & 1340 & 44.67 & 171 & 47.1 & \\
\hline $3^{\text {rd }}$ Trimester & 685 & 22.83 & 107 & 29.48 & \\
\hline Total & 3000 & 100 & 363 & 100 & \\
\hline
\end{tabular}

Table 4: Organisms isolated.

\begin{tabular}{|c|c|c|c|}
\hline Organism & Number & Percentage & Significance \\
\hline Escherichia coli & 206 & 56.75 & \multirow{6}{*}{$\mathrm{p}<0.0001$} \\
\hline Klebsiella pneumonia & 52 & 14.33 & \\
\hline Staphylococcus saprophyticus & 46 & 12.67 & \\
\hline Staphylococcus aureus & 31 & 8.54 & \\
\hline Enterococcus fecalis & 15 & 4.13 & \\
\hline Pseudomonas aeruginosa & 13 & 3.58 & \\
\hline Total & 363 & 100 & \\
\hline
\end{tabular}

Table 5: Antibiotic sensitivity.

\begin{tabular}{|lll|}
\hline Antibiotics & No. of cases & Percentage \\
\hline Amikacin & 283 & 77.96 \\
\hline Nitrofurantoin & 319 & 87.88 \\
\hline Norfloxacin & 290 & 79.89 \\
\hline $\begin{array}{l}\text { Trimethoprim+ } \\
\text { Sufamethoxazole }\end{array}$ & 252 & 69.42 \\
\hline Pipercillin+Tazabactum & 225 & 61.98 \\
\hline Ciprofloxacin & 185 & 50.96 \\
\hline Amoxicillin+Clavulanate & 215 & 59.23 \\
\hline Vancomycin & 89 & 24.52 \\
\hline Ceftriaxone & 274 & 75.48 \\
\hline Ampicillin & 59 & 16.25 \\
\hline
\end{tabular}

Table 5 shows the frequency of sensitivity of various antibiotics. Nitrofurantoin at $87.88 \%$ is the most sensitive whereas Ampicillin at $16.25 \%$ is the least sensitive antibiotic.

\section{DISCUSSION}

Asymptomatic bacteriuria of pregnancy needs special attention, due to lack of symptoms and its adverse consequences in pregnancy. ${ }^{11}$

It gives a clear predisposition to the development of symptomatic UTI, which in turn pose a risk to the mother and fetus.
Incidence of asymptomatic bacteriuria in our study was $12.1 \%$. The global prevalence of bacteriuria in pregnancy varies from $4 \%$ to $23.9 \%$ in studies conducted by various authors. ${ }^{12-14}$ Incidence in studies conducted by Maryam Kasraeian et al, Vaishali et al and Ansari HQ et al among pregnant women correlates with the present study. ${ }^{14,15}$ This high prevalence is attributed to their socioeconomic status, lack of personal and environmental hygiene.

In our study population, highest incidence of asymptomatic bacteriuria was noted in majority of the mothers $(52.89 \%)$ who fall between the age group 20 to 30 years of age. Concurrence with ours, Khan $\mathrm{S}$ et al, (64.04\%), Sudha et al, (52\%) and Sujatha et al, (72.72\%) also reported high prevalence among antenatal mothers within this age group. ${ }^{16-18}$ While Mukherjee et al (61.90\%) in age group (26-30) years, Belgaum and Raichur found that $57 \%$ and $52 \%$ of the cases belonged to (26-35) years. ${ }^{11}$ This high incidence of asymptomatic bacteriuria in young reproductive age group is due to early marriage and childbearing in our country, especially in rural sector.

Highest incidence of ASB (47.1\%) was noted in second trimester. Similar, findings was observed by Mukherjee et al $(42.80 \%)$ and Prasanna et al $(49 \%)$, whereas Hassan et al noted a higher incidence of cases $(61.77 \%)$ in third trimester. ${ }^{19}$ This might be due to the fact that majority of the antenatal women $(44.67 \%)$ were first detected in second trimester. 
Bacterial isolates have been changing from time to time and from place to place.

Our study did not encounter polybacterial isolation. In the present study, gram negative bacteria were more frequently $(74.66 \%)$ isolated than gram positive bacteria (25.34\%), which were very much similar to Prasanna et al, out of those isolates from asymptomatic antenatal mothers, we documented that E.coli $(56.75 \%)$ was the most common gram negative bacterial pathogen followed by Klebsiella sp. $(14.33 \%)$ and others. ${ }^{20}$ Most of the other studies have reported $E$. coli as the most common pathogen but with higher isolation rates than our study $(72.72 \%, 77.77 \%, 70.8 \%, 67 \%)$, while studies done in Iran and Hassan showed almost similar isolation rate of E. coli $(58.96 \%$ and $51.61 \%)$ as in our study. ${ }^{11,19-23}$ In contrast Sahira et al, reported Klebsiella sp. followed by E. Coli as the commonest pathogen. ${ }^{24}$

This pattern could be due to the fact that urinary stasis is common in pregnancy and since most Escherichia coli strains prefer that environment, they cause UTI. Another reason could be as a result of poor genital hygiene practices by pregnant women with distended abdomen who may find it difficult to clean their anus properly after defecating or clean their genital after passing urine. ${ }^{25}$

Antibiotic treatment need to be directed towards the specific pathogen cultured in pregnant women with ASB. The result of drug sensitivity revealed that $87.88 \%$ of isolates were sensitive to Nitrofurantoin (highest) followed by Norfloxacin (79.89\%) and Amikacin (77.96\%). This finding well correlates with the other studies carried out in Bangladesh, Pakistan and Ghana. ${ }^{26-}$ ${ }^{28}$ Nitrofurantoin in pregnancy appeared to be safe and a survey on physicians confirmed that most practitioners adhered to recommend prescribing nitrofurantoin in pregnancy. ${ }^{29}$

\section{CONCLUSION}

Asymptomatic bacteriuria is quite common in pregnancy. Pregnancy enhances the progression from asymptomatic to symptomatic bacteriuria. The adverse effects of undiagnosed asymptomatic bacteriuria on the mother which could lead to hypertension, preeclampsia, septicaemia, pyelonephritis and adverse perinatal outcomes such as prematurity, low birth weight, and higher foetal mortality rates have made us to suggest routine urine culture screening for all pregnant women attending antenatal clinic, preferably in the preconceptional period or at-least in the $1^{\text {st }}$ trimester with repeat culture done in every trimester. Once ASB is recognized during pregnancy, it should be appropriately treated with antibiotics and promptly followed up.

\section{Funding: No funding sources}

Conflict of interest: None declared

Ethical approval: The study was approved by the Institutional Ethics Committee

\section{REFERENCES}

1. Stamm WE, Hooton TM. Management of urinary tract infections in adults. $\mathrm{N}$ Engl $\mathrm{J}$ Med. 1993;329:1328-34.

2. Sampson JE, Gravett MG, Other infectious conditions in pregnancy: James DK, Steer PJ, Weiner CP, Govik B eds. High Risk pregnancy, management options $2^{\text {nd }}$ Edition, London WB Saunders; 1999:559-598.

3. Patterson TF, Andriole VT. Detection, significance and therapy of bacteriuria in pregnancy. Infect Dis Clin North Am. 1997;1:593-608.

4. Kremery S, Hromec J, Demesova D. Treatment of lower urinary tract infection in pregnancy. Int $\mathrm{J}$ Antimicrobe Agents. 2001;17(4):279-82.

5. Tayo AO, Akinola OI, Ottun TA, Onakoya JAA, Ogunsanya AO. An appraisal of asymtomatic bacteriuria in pregnancy- The Lagos State University teaching hospital experience. Niger J Clin Med. 2010;3(2):1-8.

6. Sharma JB, Sharma S, Gulati N, Malik S, Saini S. Prevalence of significant bacteriuria in preterm labor. J Obstet Gynecol India. 1990;40:336-8.

7. Meis PJ, Michielutte R, Peters TJ, Wells HB, Sands RE, Coles EC, et al. Factors associated with preterm birth in Cardiff, Wales. Am J Obstet Gynecol. 1995; 173:597-602.

8. Kehinde AO, Adedapo KS, Aimaikhu CO, Olayemi O, Salako B. Significant bacteriuria among asymptomatic antenatal clinic attendees in Ibadan, Nigeria. Trop Med Health. 2011;39(3):73-6.

9. Darzé OI, Barroso U, Lordelo M. Clinical predictors of asymptomatic bacteriuria during pregnancy. Revista Brasileira de Ginecologia e Obstetrícia. 2011;33(8):196-200.

10. Rajaratnam A, Baby NM, Kuruvilla TS, Machado S. Diagnosis of asymptomatic bacteriuria and associated risk factors among pregnant women in Mangalore, Karnataka, India. J Clin Diag Res. 2014;8(9):OC23.

11. Kerure RD, Umashanker. Prevalence of asymptomatic bacteriuria among pregnant women in a tertiary care hospital. Int J Sci Res Publ. 2013;3(11):1-4.

12. Qudsia H. Prevalence of asymptomatic bacteruria and associated risk factors among antenatal women attending a tertiary care hospital. J Med Allied Sci. 2011;1(2):74-8.

13. Mackejko AM, Schaeefer AJ. Asymptomatic bacteriuria and symptomatic urinary tract infection during pregnancy. Urol Clin North Am. 2007;34(1):35-47.

14. Kasraeian M. Prevalence of asymptomatic bactetiuria among pregnant women in Shiraz, Iran. Saudi Med J. 2009;30(7):917-20.

15. Jain V, Das V, Agarwal A, Pandey A. Asymptomatic bacteriuria and obstetric outcome following treatment in early versus late pregnancy in north 
Indian women. The Indian $\mathrm{J}$ Med Res. 2013;137(4):753.

16. Khan S, Rashmi, Singh P, Siddiqui Z, Ansari M. Pregnancy-associated asymptomatic bacteriuria and drug resistance. J Taibah University Med Sci. 2015;10(3):340-5.

17. Kerure SB, Surpur R, Sagarad SS, Hegadi S. Asymptomatic bacteriuria among pregnant women. Int J Reprod Contracept Obstet Gynecol 2013;2(2):213-6.

18. Sujatha R, Nawani M. Prevalence of asymptomatic bacteriuria and its antibacterial susceptibility pattern among pregnant women attending the antenatal clinic at Kanpur, India. J Clin Diag Res. 2014;8:4.

19. Gayathree L, Shetty S, Deshpande SR, Venkatesha DT. Screening for asymptomatic bacteriuria in pregnancy: an evaluation of various screening tests at the Hassan district hospital, India. J Clin Diagn Res. 2010;4(4):2702-6.

20. Prasanna B, Naimisha M, Swathi K, Mahaboob V. Prevalence of asymptomatic bacteriuria in pregnant women, isolates and their culture sensitivity pattern. Int J Curr Microbiol App Sci. 2015;4(8):28-35.

21. Neupane MS, Dhakal KS, Neupane HC, Adhikari S, Aryal B. Asymptomatic bacteriuria among pregnant women attending the outpatient clinic of Chitwan medical college teaching hospital, Chitwan, Nepal. Int Res J Pharm. 2012;3(11):78-80.

22. Jennifer P, Cyril R, Piyumi P, Nimesha G, Renuka J. Asymptomatic bacteriuria in pregnancy: prevalence, risk factors and causative organisms. Sri Lankan J Infect Dis. 2012;1(2):42-6.

23. Enayat K, Fariba F, Bahram N. Asymptomatic bacteriuria among pregnant women referred to outpatient clinics in Sanandaj, Iran. Int Braz J Urol. 2008;34(6):699-707.

24. Dimetry SR, El-Tokhy HE, Abdo NM, Ebrahim MA, Eissa M. Urinary tract infection and adverse outcome of pregnancy. J Egypt Public Health Assoc. 2007;82:3-4.

25. Imade PE, Izekor PE, Eghafona NO, Enabulele OI, Ophori E. Asymptomatic bacteriuria among pregnant women. North Am J Med Sci. 2010;2(6):263-6.

26. Selimuzzaman ABM. Asymptomatic bacteriuria during pregnancy: causative agents and their sensitivity in Rajshahi city. The J Teachers Association RMC, Rajshahi. 2006;19(2):66-9.

27. Khattak AM. Antimicrobial sensitivity pattern of urine isolates from asymptomatic bacteriura during pregnancy. Biomed. 2006:22.

28. Institute of Medicine. Preventing low birthweight. Washington, DC: National Academy Press; 1985:4693.

29. Romero R, Oyarzun E, Mazor M, Sirtori M, Hobbins JC, Bracken M. Meta-analysis of the relationship between asymptomatic bacteriuria and preterm delivery/low birth weight. Obstet Gynecol. 1989;73:576-82.

Cite this article as: Basumatary BK, Dutta BK, Choudhury N. Asymptomatic bacteriuria among pregnant women attending antenatal clinic at a tertiary care centre. Int J Reprod Contracept Obstet Gynecol 2020;9:528-32. 